\title{
Seller and buyer obligations and guarantee of its implementation in the trade law of Iran and Egypt
}

\section{Obligaciones del vendedor y comprador y garantía de su implementación en la legislación comercial de Irán y Egipto}

\author{
Saeed Sharafoddin Tabatabai \\ $\mathrm{PhD}$ student in Jurisprudence and Fundamentals of Islamic Law, Mashhad Branch, \\ Islamic Azad University, Mashhad, Iran \\ https://orcid.org/0000-0001-8561-0286

\section{Seyed Mohsen Razmi} \\ Assistant Professor, Department of Jurisprudence and Law, Mashhad Branch, Islamic \\ Azad University, Mashhad, Iran \\ https://orcid.org/0000-0002-3853-5348

\section{Mostafa Rajaeipoor} \\ Assistant Professor, Department of Jurisprudence and Fundamentals of Islamic Law, \\ Mashhad Branch, Islamic Azad University, Mashhad, Iran \\ https://orcid.org/0000-0002-0314-3344
}

Received 09-08-20 Revised 10-10-20

*Correspondence

Email: razmi0109@mshdiau.ac.ir
Cite as:
Tabatabai, S., Razmi, S.M., \& Rajaeipoor, M. (2021). Seller and buyer obligations and guarantee of its implementation in the trade law of Iran and Egypt. Propósitos $y$ Representaciones, 9(SPE3), e1120. http://dx.doi.org.10.20511.pyr2021.v9nSPE3.1120 


\section{Summary}

The purpose of this article is to study the obligations of the parties to the law in Iran and Egypt and guarantee its implementation. The main question that has been proposed and examined in this regard is what are the obligations of the seller and the buyer in the law of Iran and Egypt? And how can the guarantee of its implementation be assessed in the law of the two countries? The present article is a descriptive-analytical and examines the question using the library method. The results of this research show that by concluding a series of obligations, the parties will be responsible which must be observed, which have the same view of these obligations in both laws; obligations such as delivery of price and cost are the delivery of both documents. Of course, there are differences in the guarantee of fulfillment of obligations and effects. In Iran law, unlike in Egypt law, the effects of termination appear from the time of the termination, not from the time of the contract, therefore, until the day of termination, the contractor leaves all his works so, the return of benefits is from the day of termination; another major difference is that in the case of Iran law, loss, defects or transfer of goods do not preclude termination, except in the case of discretion. What can be concluded is that in Egyptian law, the return of benefits is officially accepted, but the legislator in Iranian law has not explicitly commented on this.

Keywords: Obligations, Seller, Buyer, Performance Guarantee, Iran, Egypt.

\section{Resumen}

El propósito de este artículo es estudiar las obligaciones de las partes de la ley en Irán y Egipto y garantizar su implementación. La cuestión principal que se ha propuesto y examinado a este respecto es ¿cuáles son las obligaciones del vendedor y del comprador en la legislación de Irán y Egipto? ¿Y cómo se puede valorar la garantía de su implementación en la legislación de los dos países? El presente artículo es de carácter descriptivo-analítico y examina la cuestión mediante el método de biblioteca. Los resultados de esta investigación muestran que al concluir una serie de obligaciones, las partes serán responsables las cuales deben ser observadas, las cuales tienen la misma visión de estas obligaciones en ambas leyes; Obligaciones como entrega de precio y costo son la entrega de ambos documentos. Por supuesto, existen diferencias en la garantía de cumplimiento de obligaciones y efectos. En la ley de Irán, a diferencia de la ley de Egipto, los efectos de la rescisión aparecen desde el momento de la rescisión, no desde el momento del contrato, por lo tanto, hasta el día de la rescisión, el contratista deja todas sus obras por lo que la devolución de los beneficios es desde el día de la terminación; otra diferencia importante es que en el caso de la ley de Irán, la pérdida, los defectos o la transferencia de bienes no excluyen la rescisión, excepto en el caso de discreción. Lo que se puede concluir es que en la ley egipcia, la devolución de beneficios está oficialmente aceptada, pero el legislador en la ley iraní no ha comentado explícitamente sobre esto.

Palabras clave: Obligaciones, vendedor, comprador, garantía de cumplimiento, Irán, Egipto.

\section{Introduction}

Man is a civil being by nature, that is, he is not able to meet his needs alone, they inevitably need economic, cultural, political participation, in order to advance its economic goals, it needs a set of rules and contracts, all of which are based on the contract of sale, in fact, jurisprudential discussions have referred to it as the mother of contracts, sale is the transfer of money to another property, which is one of the signatures of the holy sharia, sale in the word means buying and selling and trading (Lewis, 2001: 120). In jurisprudential terms: it is a requirement and acceptance that indicates the transfer of property in exchange for a known and determined exchange(Shahid I , 2003, J 2: 12). The second definition of sale; Demand and acceptance are complete from both sides [mature, wise, autonomous, with intention and will]. Which is transferred to the other party with the consent of both parties in exchange for a definite and known exchange (Shahid I, 1414, J 1: 191). In legal terms, its meaning is not separate from its literal meaning, it is a contract or 
agreement under which a person transfers money to another person in exchange for another's property, In such a way that the owner of the property (seller) transfers ownership of his goods in exchange for the wealth or money he receives to the other party (buyer) and the party also gives his money or property to the seller in exchange for receiving the goods. This issue has elements that can be referred to the parties (seller, customer) price. Trade is the face-to-face exchange of goods and services between two parties on the basis of paper documents, looking around, hundreds of different types of trade, it can be seen as selling goods, buying from a shop, working in a company and so on. There are different roles in these areas such as buyer, seller and producer. In addition, obligations such as delivery of price and payment, delivery of documents related to trade, obligations of the obligee and the obligee during the execution of the contract of sale and after the sale, the executive guarantees of these obligations, which include termination, termination option, ignorance, grumbling, etc., can be expressed. In the present study, with the title of obligations of citizens in sale from the perspective of Shiite jurisprudence by applying the commercial law of Iran and Egypt, while stating the obligations of the seller and the customer and guaranteeing the fulfillment of these obligations, which include termination, optional termination, grievances, etc. are also expressed which according to the legal system, each country in its legal system has set rules for the strength and validity of contracts that according to which the contractors are obliged to fulfill their obligations. The obligations of each party are specified and executive guarantees are provided for the fulfillment of the obligations. What is very important in this regard are the rules that force the offender to fulfill the obligation or to bear the damages caused to the oblige. Defining the obligations of the parties to the contract of sale in jurisprudence and law of Iran and Egypt and expressing common and different relations between them and expressing the guarantee of their performances and creating harmonization of these systems in the international dimension and interpreting them according to establishing economic relations between different sections of society for growth and It is maturing, From the above, the purpose and necessity of our research is clear. In this article, an attempt has been made to make a comparative study of the obligations of the seller and the buyer and the guarantee of its implementation in the trade law of Iran and Egypt. In this regard, first the obligations of the seller and the buyer in the law of Egypt and Iran are examined, then, the guarantee of fulfillment of the obligations in the law of Iran and Egypt is examined.

\section{Obligations of seller and buyer in Egypt and Iran law}

In this article, examines the obligations of seller and buyer in Egypt and Iran law.

\section{Seller's obligations}

According to the Egypt Commercial Law, if the parties agree that the determination of the shape of the seller or the volume and size of the seller or otherwise is one of the characteristics that characterize the seller, it is the responsibility of the customer, It is obligatory on the customer to determine the shape of the seller either at the time agreed upon or at the appropriate place if the parties have agreed; Otherwise, it is permissible for the seller to request the termination of the sale or to exchange the goods. If the amount sold is specified in the contract, the seller is liable for any loss in the amount in accordance with custom, unless otherwise agreed, Therefore, the buyer does not have the right to terminate the contract in terms of the seller's loss unless he proves that the loss is so important that if he was aware of it, he would not have closed the contract. The Civil Law of Iran (Article 384) stipulates: If the seller is in a certain amount and less than that amount at the time of delivery, the customer has the right to cancel the sale or accept the existing price by paying a part of the price in proportion to the existing one, and if the seller is more than a certain amount, the seller's excess is the property.

The first part of Article 435 of the Egypt Civil Law stipulates in the definition of surrender: "Surrender means that the seller is placed in the possession of the customer in such a way that the customer can possess the property and profit from it without any obstacle, even if it has no material dominion over it, provided that the seller informs the customer about it". According to Article 93 of the Egypt Commercial Law, if the place of delivery of the seller is not specified, the seller is obliged to deliver the goods as soon as the contract is concluded, which requires the nature of the seller, or custom requires another place to be determined. Anything that is considered 
a part or function of the transaction according to custom and habit, or the evidence indicates its entry into the seller, the inside is in the transaction and belongs to the customer, even though it is not explicitly mentioned in the contract, and even though the parties are ignorant of custom.

If the price of the transaction is reasonable, the seller can stipulate that the transfer of ownership to the buyer is suspended for payment of the full price even if the transaction has been delivered. If the payment is in installments, the parties can agree that the seller will keep part of the price as compensation for termination of the transaction if the full installments are not paid. When all the installments are paid, the transfer of ownership of the transaction to the buyer is considered from the date of the transaction.

According to Article 435 of the Egypt Civil Law, 1. Surrender includes making the transaction available to the buyer in such a way that he can seize it and use it without hindrance, even if he does not have material dominion over it, provided that the seller informs the buyer that the transaction is in his possession, the surrender is made according to the nature of the transaction. 2. If the transaction is in the possession of the buyer before the transaction or the seller retains the transaction after the transaction for a reason other than ownership, the surrender shall be effected as soon as the parties agree.

In Egypt law, surrender is present or decree. In the beginning of Article $435 \mathrm{BC}$, Egypt defined the actual surrender as follows: "The transaction should be taken over by the customer, so that the customer is able to collect and benefit from it without hindrance, although he does not actually seize it, in this case, he must inform the customer that the transaction is his possession". According to this article, the current seizure is not a condition and as soon as the elements of complete surrender are assumed to be complete surrender (Abu Al-Saud, 2010: 283). In some cases, surrendering a sentence replaces the current surrender. Pursuant to the second part of Article 435 of the Civil law, the submission of a sentence to the conciliation of the parties is realized. Judicial surrender is distinguished from actual surrender by agreement or legal possession and does not occur by material act. Judicial surrender has two forms: 1- The transaction is in the possession of the customer before the price. 2- The transaction should be in the possession of the seller after the sale. Surrender in accordance with Article 402 BC of Egypt has two elements:

1- Putting the seller under the control of the customer in such a way that he can benefit from it without any obstacles. 2- The seller must inform the customer that the seller is in possession of him. This awareness is not specific and may be formal (Labiba Saturday and Sabhiya Khalil, 1968: 169). It is observed that the mere obligation of the seller to place the seller under the possession of the customer includes the declaration to the customer that he has actually placed the seller under his possession (Raja'a, 2000: 148). If these conditions be provided, the surrender is valid and its legal effects will be created. In Egypt civil law, the most important of these effects is the transfer of the result of the loss from the seller to the customer (exchange guarantee) (Qasimah, 2008: 264). According to Egypt law, surrender has no role in the transfer of ownership and is merely the performance of a contract. Performance by which the customer becomes the beneficial owner of the profit and management of the goods, without any obstacle in this regard (Al-Sharqawi, 1975: 191).

The Iran Civil Law (Article 373) states: If the seller has already been in the possession of the customer, he does not need a new bill and it is also in the price. According to Article 437 of the Egypt Civil Law, if the seller is lost before surrendering to a cause outside the seller's authority, the sale is canceled and the price is returned to the buyer, unless the loss is made after the seller notifies the buyer to receive the seller, It is also stated that if the seller dies before delivery without fault and negligence on the part of the seller, the terminated sale and the price must be returned to the customer, Unless the seller has referred to the governor or his deputy for surrender, in which case the customer will lose property.

According to Article 93 of the Egypt Commercial law, if the parties agree that the customer determines the place of delivery of the goods, the seller is required to deliver the goods to the place specified by the customer. Of course, taking into account the period of time when the nature of the seller requires preparation for delivery and delivery of goods, If the value of the seller decreases in terms of corruption before delivery, if the decrease in value is so severe that the sale would not take place if it had taken place before the conclusion of the contract, the buyer has the right to cancel the sale or accept the sale at a reduced price. 
If the seller has repeatedly surrendered to the seller, the customer is allowed to request the termination of the transaction if the seller does not deliver one of the times they met at that place and if the payment of some of the seller causes a great loss to the customer, it will terminate the number of times the delivery of the seller is completed.

If the price is not paid at the time it happened, the seller is allowed to sell part of the goods, Of course, after the customer is excused to return it, and if it is sold in good faith at a price less than the amount between the parties, the seller has the right to request that amount of difference between the two prices from the customer, and if the price for a part of the seller is known in the market, The seller can claim from the customer even though he has not yet returned the sale, the amount of the difference between the price agreed upon by the contractors and the price of the part of the seller in the market, which is the price of the day on which the price is set for payment.

\section{Obligations of the buyer in the law of Iran and Egypt}

The price must be paid at the place where the seller was delivered, unless agreed or to the contrary. If the price is not payable at the time of delivery, the price must be paid at the place of residence of the buyer and on time.

According to Article 394 of the Iran Commercial Law, the customer must pay the price on time and on the deadline and in accordance with the conditions stipulated in the contract of sale. 1The price must be paid at the time of delivery of the seller, unless otherwise agreed by the parties or the custom to the contrary.

2- Whenever a third party interferes with the buyer based on the former right to the sale or the seller, or if there is a fear of eviction from the buyer, the buyer can use the right of price confiscation if the terms of the contract do not prevent him, in order to eliminate the inconvenience or eliminate the risk, therefore, in such a case, the seller can demand payment of the price in exchange for providing a guarantor.

3- The interests and views of the seller from the time of sale belong to the buyer and the cost belonging to the seller from that date is also on him, unless otherwise agreed by the parties or the custom to the contrary.

If all or part of the price is present, the seller can keep the seller until he has received the relevant price, even if the buyer provides collateral or guarantee, this right of confinement is when the seller has not given the buyer a deadline after the sale. If the seller dies in the sale and while exercising the right of liberty, the buyer is liable for the loss unless the seller has lost as a result of the seller's action. The costs of the sale document, stamp, registration of the document and other costs are the responsibility of the buyer otherwise agreed by the parties or the custom to the contrary. If the agreement of the parties or custom does not specify the place or time for surrender the buyer must pay the price at the place where the seller was at the time of sale and transfer it immediately, unless the transfer requires appropriate time.

In Egypt law, citing paragraph 1 of Article 205 of the Civil law, it is stated:

"Objects that are typically definite, the property is transferred to the customer by separation. Although the surrender is after separation. But separation can be achieved by surrender, either by placing the mark of the customer's property on it, or by placing the customer's influence on it" (Al-Sunuri, 2009: 428/4; Abu al-Saud, 2010: 198). Article 933 BC of Egypt also stipulates in this regard:" Movable property of a certain kind. According to Article 205 of the Civil law, its property is transferred by separation." In English law, the terms "property" and "physical possession" are quite distinct. The goods may still belong to the seller, while in the possession of the buyer, or vice versa".

According to Article 377 of the Civil law of Iran, each seller and customer has the right to refuse the decision of the seller or the price until the other party agrees to surrender, unless the seller or the price is valid, then any of the seller or the price that is present must be submitted.

If the custom in terms of transaction costs or place of delivery is contrary to the order mentioned or otherwise stipulated in the contract, must be treated as usual or conditional in the contract and citizens can also change it to compromise. The costs of delivery of the seller, such as the cost of transporting it to the place of delivery, renting and weighing, etc., are the responsibility of the seller, and the costs of delivery of the price are the responsibility of the buyer. 
Under Egypt law, if the subject is a pledge of money, the seller cannot be forced to accept promissory notes, bills, checks, postal remittances, stocks, bonds or other securities instead and if the seller agrees with receiving them, the obligation will not be converted. (Al-Sunnahuri, 2009, vol. 3, p. 755).

The first assumption made by the Iran legislature regarding the time of delivery of the seller is to determine the date of fulfillment of the obligation in a certain time this issue is inferred from the opposite concept of Sadr's article. Both provisions therefore provide that the parties may, in the contract, set a time limit for the performance of the obligation and if the provisions of the contract can be determined implicitly at the time, it can be considered as the time of fulfillment of the seller's obligation.

\section{Guaranteeing the fulfillment of obligations in the law of Iran and Egypt}

In the laws of Iran, surrender and its effects are external factors and the payment of price and fulfillment of commitment, internal factors of psychological peace, etc., are social motivators, the surrender of the seller and the price and its rulings in jurisprudential texts have about 33 rules directly and indirectly, and in the subject law of Iran, 18 articles of the civil law are directly assigned to it. The guarantee of fulfillment of the obligation to surrender is also expressed in different forms, such as the obligation to surrender (fulfillment of the same obligation) and termination and claim for damages. In the studied legal systems, the compulsion to surrender or the compulsion of the obligee is accepted to some extent, not only do they not consider it contrary to human originality and dignity, but they also consider it very natural and logical. In a sale contract, most of the obligations are related to the seller, and each legal obligation carries a performance guarantee that will be applied in case of violation of that obligation.

\section{Obligation to surrender (fulfillment of the same obligation)}

In law of Iran, the principle is based on compulsion to fulfill the same obligation (Ali Ahmadi, 1996: 259, Qasemzadeh, 2009: 218 - Katozian, 1989: vol. 3, 226). In other words, the principle is that if the obligor does not voluntarily fulfill his obligation, first, he must be asked to fulfill his obligation by the competent authorities, and if execution is not possible, the issue of termination and claim for damages will be raised. From the owner of Articles 237 and 238 of the Civil law regarding the condition, it is received that in the main obligations, the obligor must first be forced to fulfill the obligation, and if the obligation is impossible, and the obligation should not be among the actions that another can perform on behalf of the obligor, the other party will have the right to terminate the transaction. Therefore, in Iran law, both in the main obligations (Articles 376-395 $\mathrm{BC}$ ) and in the implicit obligations (Articles 237-240 BC), the principle is that the obligor must first fulfill the obligation and in case of excuse of coercion, other compensations are proposed. Contrary to the opinion of some writers who have terminated the word can in Article 237 on the ability to leave coercion and authority (Sadeghi Neshat, 2009: 312) Or a proposal to consider the construction condition of termination of the transaction in case of violation of the execution (Khidmatgozar, 2008: 199). Comparing the appearance of the mentioned materials with the expressions expressed in jurisprudence (Darabpour, 2000). shows that the civil law is one of the sayings of the jurists who have compelled the obligation obligatory with a condition and termination (Hosseini Ameli, 1418: v. 2, 281, Khoei, 1987: vol. 7, 396, Rouhani, Bita: vol. 6, 302). has not followed.

Obligation to submit (fulfillment of the same obligation) is the priority of guaranteeing the fulfillment of the obligation of the buyer and the seller. Of course, it should be noted that one of the terms of the transaction, which is in fact considered the legal terms of the contract; Possibility of surrender means that the transferor has the ability to surrender the contract to the transferee or the obligor. Article 348 of the Civil law the sale of something that the seller has no power to surrender is void. "Ability to surrender is among the attributes of the buyer and besides the purchase" and can be "taxable and have a rational benefit" and the legislator in the article "and the sale of $348 \mathrm{BC}$. Asked "prohibit financial transactions that, by their nature, cannot be made 
available to the parties". Because if it was their personal ability, the power to surrender would be a condition of the two parties to the transaction.

According to the relevant jurisprudential and legal principles (Article $348 \mathrm{BC}$ ) and the texts that indicate the invalidity of the vague transaction, it should be considered that the power to surrender the subject of the transaction is a condition for the validity of the contract and in cases of doubt about the existence of power, the transaction is void. The guarantee of the fulfillment of the obligation to surrender the buyer in Iran jurisprudence and law is the International Convention on the Sale of Goods with a comparative study of British law and according to the principle of accepting the survival of power and the principle of validity of the contract or jurisprudential generalities related to the validity of the contract in doubtful cases cannot prove the validity of the contract (Shahidi, 2013, vol. 5). In Imami jurisprudence, the power to surrender the subject of the transaction is declared a condition for the validity of the sale, and a consensus is claimed on this matter, the sale of something that cannot be normally seized and surrendered has been declared invalid (Ansari, 1990, J 2: 85). Another group of jurists pointed to the ambiguity of a transaction in which there is no power to surrender the buyer, and "and our followers" cited a prophetic Hadith in support of their opinion, and they believe that the buyer of "You do not have" and the seller should trade with open eyes, and each to know what they will achieve in return for what they give and that is why they have forbidden the vague or dubious transaction and have made the ability to surrender one of its correct conditions (Emami, 1994, J 1: 260).

The jurists believe that the surrender of the transaction is void if it is non-surrender and surrender, like the sale of fish in the sea and traded in a certain way, also, according to some, the lack of relative power of the parties to the transaction invalidates the transaction, in case of absolute power to surrender, if the transaction was possible at the time of concluding the surrender but before the surrender or surrender, the power to surrender is revoked, if the seller is the same and the ownership has been created since the contract, the inability of the seller from the time of its occurrence will cause the termination of the contract (Katozian, 2008, vol. 2: 220).

The compulsion to surrender or the compulsion to commit is so acceptable that not only is it not considered contrary to human originality and dignity, but it is also considered very natural and logical. "Using Article 532 BC and Articles 380, 376, 237, 238, 376, 476, 534 and 779 BC. Iran" In all obligations, if the obligation is not fulfilled, the obligor is required to first request the fulfillment of the same obligation and if coercion is not possible, terminate the contract. Iran civil law does not have a clear rule regarding the right to coercion to perform the same obligation as a guarantee of fulfillment of obligations. Given that the contract of sale and its general rules are largely current in other contracts and agreements and the general principles governing this legal subjects are applicable to other legal entities. This rule is in Article $237 \mathrm{BC}$ regarding the conditions during the contract and in Article 476 BC. It is stated about the main obligations of the landlord (Safaei et al., 2011: 224).

According to Article 454 of the Civil law: "If the customer has leased the seller and the sale is terminated, the lease will not be canceled unless the expropriation of the carrier is explicitly or implicitly stipulated in the interest of the customer, in which case the lease is void." Also according to Article 455 of the Civil law: "If after the contract of sale, the customer deprives all or part of the seller of the right, for example, if you mortgage to someone, the termination of the transaction will not cause the deterioration of that personal right, unless the condition is violated. From the provisions of the above two articles, a rule can be deduced according to which the possession of a party that is the result of a contract of ownership is effective in the matter of ownership and subsequent termination does not harm it, otherwise implied or explicitly agreed. However, Article 460 of the Civil law provides for "conditional sale": "In a conditional sale, the customer cannot take possession of the seller, which is in the interest of the option, such as transfer, etc." Elsewhere, Article 500 of the Civil law nullifies lease contrary to the seller's right. These materials seem to contradict the aforementioned rule. But with a little reflection it can be seen that in the conditional option, the two parties agree that the buyer keeps the property ready to return to the seller and the requirement of the provisions of the conciliation is to avoid taking possession contrary to the performance of authority. Therefore, the authority of the condition should be included in the cases in which "the non-possession of the carrier has been implicitly conditioned on the benefit of the customer." 
There is the same inference in Egypt law. Article 160 of the Civil law of that country provides: "If the contract is terminated, the parties will return to the state as if there was no contract." This article is a general rule that the authors of the legal system believe is critical in all types of termination (judicial, accidental and legal); therefore, termination of sale has a retroactive effect and this effect appears from the beginning of the contract.

The power of surrender is necessary in order for the transaction to be available to the party in due time and it does not take place before the time of surrender so that the power to surrender is necessary and it will be useless to have the power to surrender in the time before the contract is executed. If "Article $370 \mathrm{BC}$ stipulates in this regard that the parties to the transaction have set a deadline for submission." Power is a condition for surrender at that time (Katouzian, 2012, J 1: 118). must be achieved with certainty.

\section{Termination and claim for damages}

In Iran law, if the obligor is harmed due to non-fulfillment or delay in the obligation, he can request it from the obligor. Because this damage has been inflicted on the obligee by the obligee due to non-fulfillment of the obligation in due time and according to the rule of reason, whoever harms another must compensate it, therefore, the obligee must pay it to the obligee. Article 221 of the Civil law provides: "If someone commits an action or undertakes to refrain from doing something, in case of violation, he is responsible for the damages of the other party, provided that the compensation is specified or the obligation of the mystics is specified or be guaranteed by law". Article 226 also provides for the possibility of claiming damages: "In case of non-fulfillment of obligation by one of the parties, the other party cannot claim damages unless a certain period has been set for the fulfillment of the obligation and the said period has expired and if there is no time limit for fulfilling the obligation, the party can claim damages when he has the right to do so and prove that he has demanded fulfillment of the commitment". It can be deduced from the content of the above two articles that if one of the parties does not fulfill his obligation, the other party, in addition to being able to terminate the contract (with reference to Articles 237, 238 and 239 BC). also has the right to claim damages (Emami, 1994, vol. 1: 240-239). However, in some cases the obligor is not liable for damages: 1- If the obligor is the cause of non-fulfillment of the obligation, for example, if a contractor undertakes to complete a building according to certain plans within three months and to provide the building materials to the obligor. If a person delays in the preparation of materials and as a result the building is not completed within three months, the obligor is not responsible for the damages. Or in the case of a contract of sale, if the sugar factory undertakes to deliver 10 tons of sugar to the buyer on time and the buyer undertakes to deliver 30 tons of beet to the factory to prepare the said sugars, if the sugar factory does not fulfill its obligation due to non-fulfillment of the recent obligation, then the sugar buyer cannot claim damages from the sugar factory.

2- If the non-fulfillment of the obligation is due to an external reason that cannot be related to the obligor. Therefore, two sets of conditions remain in place despite the expiration of the contract and are binding on the parties:

1- Terms and conditions related to the resolution of litigation, which include arbitration, renegotiation (to resolve conflicts arising from unpredictable changes in circumstances) and issues and conditions related to the selection of the court. National legal systems often acknowledge the validity of such terms and conditions despite the termination of the contract.

2- Also conditions and restrictions that indicate the effects and consequences of non-performance of the obligation; Such as the conditions regarding the limitation of liability, including exemption from liability, increase or decrease of liability, or determination of liability up to a certain amount of damages, or determination of the manner of return of remuneration or other terms and conditions of punishment.

These conditions are consolidated by the rule of will of the parties, and in fact the contractors have demanded from the very beginning of the contract that these conditions have their binding power in case of termination of the contract.

The effects of termination are:

A) Return of the same 
The first effect of terminating the contract of sale is to return the effects of the contract to the original state; that is, if all or part of the contract has been executed, the parties must return everything they have received to the other party. It appears that each of the parties to the offense has committed a crime and Failure to perform the contract is due to his fault; he must bear the damages; In other words, the party who has not fulfilled his obligation and the non-fulfillment of the obligation is due to his fault is responsible for all damages related to the return of the goods. In some cases, only one of the parties may be required to extradite, it is at the same time that only one of the contractors has surrendered in exchange for the contract, in this case, the person who received the goods must return the goods in case of termination; However, if both parties have surrendered, in the event of termination, either party must return the goods to the other at the same time, this rule is similar to the case in which in the performance of the contract, each of the parties must execute the subject of the contract at the same time. If one of the parties fails to fulfill the obligation, the other party will be imprisoned (Article 71 of the Convention) this right to imprisonment exists both at the time of the performance of the provisions of the contract and at the time of the performance of the duties resulting from the termination of the contract. Therefore, the buyer can refuse to return the goods if the seller is not willing to return the price, and vice versa. The reason for this is the main existence according to which: "Each party can suspend the fulfillment of its obligation, provided that ... it becomes clear that the other party will not perform the essential part of its duties".

The same solution can be accepted in Iran law; therefore, as a result of termination, each of the two transactions in the same situation as it is at the time of termination, is rejected by the owner before the contract, that is, the seller is returned to the seller and the price is returned to the buyer; but in Iran civil law, what is stated in the last part of Article 81 of the Convention does not explicitly exist; In other words, in Iran law, there is no reference to the return of property after termination. However, Article 377 of the Civil law can be helpful. This article stipulates that: "Each seller and customer has the right to refuse to surrender the seller or the price until the other party agrees to surrender, unless the seller or the price is delayed In that case, any of the goods or prices that are present must be surrendered." This article, however, is included in the sale, however, the contract of sale does not have a special feature, but this principle can be considered in all current exchange contracts. In the case of termination of the contract, each of the parties to the terminated contract has an obligation towards the other party, as we grant the parties the right to terminate the contract, regarding the obligation of the parties after termination to grant the return of the parties, the right to terminate.

However, it is clear from the timing of the performance of the Convention's tasks that this task must be performed simultaneously. This is not explicitly mentioned in Iran civil law. However, in accordance with the general principles, the same solution is acceptable in Iran law. But if neither party is willing to do its job and make the fulfillment of his obligation subject to the fulfillment of the other party's obligation, the convention has not taken any measures in this regard. It seems that domestic law should be referred to in this case. There is no legal article in Iran law in this regard. The jurists also disagree in this regard, however, it seems that if both parties ask the court to coerce each other and both sides invoke the right to imprisonment, both should be coerced and at the time of execution of the sentence and surrender, the seller will be given a price if he has provided the seller to the representative of the court.

It should be noted that the bankruptcy of one of the parties may cause the return operation to be difficult. In this regard, the method of extradition and in general the various techniques available to resolve such situations are subject to domestic law as a general rule, all legal systems give the debtor an extra time limit or reduce the amount of the debt and refuse the same repayment (Darabpour, 2012, vol. 3: 163).

\section{Loss of the right of termination as a result of impossibility of return}

There is no article in Iran civil law that explicitly addresses this issue as a general rule; however, by examining the materials related to the termination of the contract, two articles are found that seem to be in conflict. Article 429 of the Civil law provides: In the following cases, the customer cannot cancel the sale and can only receive the arch: 1- In case the seller loses to the customer or 
transfers it to another 2- If a change is found in the seller, whether the change is due to the customer or not 3- If another defect occurs in the seller after receipt, unless it happened at the time of the customer-specific option, in which case it does not preclude termination.

Therefore, according to this article, if the buyer does not have the power to return the same product, the principle is that it is not possible to terminate the contract.

Breaking the transaction is also one of the cases of terminating the contract, with the difference that in breaking the transaction, the parties agree to terminate the contract. "The loss of one of the exchanges does not prevent the transaction from being disrupted in this case, instead of what has been lost, something like it will be given if it is similar and its price will be given if it is guardian." Article 286 of the Civil law provides for the dissolution of a transaction:

It can be seen that in disrupting the transaction, even the loss of one of the substitutes does not prevent the termination of the contract. Now we have to answer the question that in Iran civil law, as a general rule, does not the loss of one of the relatives or the impossibility of return prevent the termination? If this is the case, Article 282 of the principle and Article 429 are considered an exception to that principle, or, conversely, the loss of one of the substitutes or the impossibility of return, prevents the termination if this is the case, Article 429 is the rule and principle, and Article 286 is an exception to this principle.

Some jurists believe that Article 286 of the Civil law implies that the loss of one of the two transactions (except in the case of a defective option) does not prevent the termination of the contract. In this case, instead of what has been lost, such as it is given in the form of a proverb and its price is given if it is relative to the price. If the transaction is incomplete or defective, in addition to rejecting it, the defect and defect that will be compensated will be paid because a defect, like a defect, is the loss of some. The loss of some, like the total loss, will lead to the payment of compensation.

If the transaction is excluded from the customer's property by a contract, such as endowment and sale, it acts like a waste case that is, it will be exchanged for a proverb or a price. If the second transaction is terminated before giving a change in a direction such as disrupting the transaction, and Or the transaction becomes the property of the customer with a new contract, the same buyer is rejected by the seller even if the seller does not consent, because giving a ransom is in the absence of the principle and the transfer to another truth has not changed the object, if the subject of the transaction has been transferred to another unnecessary contract such as gift and voluntary sale, the customer cannot be obliged to dissolve it, instead, as in the case of loss, it will be sold (Emami, 1994, J 1: 546).

\section{Refund of benefits}

In the field of Egypt law, the legislator is more explicit and Article 160 of the Civil law of that country stipulates that if the contract is terminated, everything will return to its original state. Therefore, the seller must repay the price and its results from the day of receipt, and also the buyer must not refund the seller and its benefits from the day of the contract. (Al-Sunnahuri, 2009, Vol. 4 , p. 826) It should be noted that there is no explicit article in Iran law that states a general rule on the issue. To find a solution, we are faced with two seemingly conflicting articles: Article 287 of the Civil law regarding the disruption of a transaction and Article 459 regarding the sale of bets. The last article stipulates: "... but the manifestations and benefits obtained from the contract to the termination of the client's property". This provision expresses the subsidiary ownership of the benefits mentioned in Article 32 of the Civil law in the exercise of the right of termination: After the contract, because the existence of authority does not prevent the transfer, the seller's interest belongs to the citizenship from the principle of ownership. But after the performance of the right of termination, because the ownership returns to the seller and this change is only for the future, the benefits are from that seller; therefore, Article 459 states the rule of performance the option in one of its examples and the sentence should not be considered as a special "conditional authority".

\section{The effect of the termination condition on the law of Iran and Egypt}


When the condition of termination is met, the effects are referred to in the Egypt civil law. Article 269 of the said law stipulates: 1. when the condition of termination is fulfilled, the obligation ceases and the creditor must take what he has taken, return and if the return of the seller due to the factor caused by the person, if not, you have to deliver it in return. 2. Another effect of fulfilling the termination condition is that despite the fulfillment of the termination condition, the actions of the lender in managing the affairs related to the contract remain in force. This article is used that when the condition of termination is fulfilled, the fulfillment of that obligation eliminates the suspended obligation and as if the said obligation did not appear from the beginning and the obligation is terminated automatically without the need for a verdict or re-termination.

So first there is no need to ask for termination; because termination happens spontaneously. Second: Anyone who has an interest in terminating the contract can rely on it; for example, after the dissolution of the customer's contract, the creditors of the seller can take over the seller independently, third, the parties cannot agree to recourse to the right of termination; because the contract is considered terminated by itself and in order for the effect of the contract to remain, they must enter into a new contract (Al-Sunuri, 2009, vol. 3: 57-55).

In Articles 265-269, the legislator of Egypt has explicitly spoken about the nature, rulings and effects of the termination condition and has recognized it as a suspended condition.

The condition for termination is one of the types of suspension, and just as some contracts must be given in a concise and non-suspended form, here, too, it is the deterioration of the contract that depends on the fulfillment of the condition;

In other words, the condition of dissolution has an effect on a contract that can be dissolved at will. A contract that cannot be dissolved by the will of one of the parties or as a result of a conciliation is not invalidated by the condition of termination; for example, a marriage contract cannot be disrupted and the parties cannot suspend its deterioration either voluntarily or by force and its termination is limited to the cases provided for in the law, and the marital relationship cannot be dissolved except through divorce. Therefore, the condition of dissolution is not in it and the couple cannot compromise the occurrence of an event that causes the dissolution of the contract.

For this purpose, contracts are divided into several types in terms of termination and termination: 1- A group of contracts that do not require a special reason to destroy them and are destroyed by reasons such as termination, disruption of the transaction or cancellation. Contracts such as sale, rent, peace, mortgage, farm irrigation, remittance and sponsorship are in this category. 2- Another group of contracts according to some social and moral interests are such that the legislator and the legislator, due to the importance of these contracts, consider their termination to require a special cause or community of conditions. Marriage, endowment and guarantee are included in this category of contracts.

It seems that according to this classification, it is possible to include the termination condition in the first group, but in the second group, there is no condition for dissolution. The endowment contract is the same. The endowment must be permanent and the endowment cannot regain the endowed property by dissolving the endowment. Therefore, it must be admitted that the inclusion of the termination condition indicates that the purpose was not endowment (permanent imprisonment). At the disposal of the condition, the situation is the same and insertion of the condition of authority and the condition of termination with the requirement of endowment of usufruct and termination of property relationship. It is the opposite and it invalidates it (Katozian, 1998, vol. 3: 173).

Article 226 of the Egypt Civil law explicitly states two important and basic conditions in both the condition of endowment (suspension of the existence and conclusion of the contract) and the condition of termination. The said article stipulates:

1- When (the contract) is suspended on an impossible condition (impossible) or a condition contrary to public order or good morals, the said obligation does not arise (it is not valid). Of course, this is the non-influence and invalidity of the obligation if the condition is known; but if the condition is terminated, only the condition itself is invalid.

2- Nevertheless, the obligation suspended on the condition of termination, which is contrary to good morals or public order, is not valid; (Of course) when the condition stipulates the obligation (Sultan, Anwar, 1983, p. 78). 
It is inferred from the text of the article that when the condition of termination is impossible or contrary to public order or good morals, it is invalid and because an obligation that is suspended on the condition of termination is an effective and immediate obligation and the deterioration of the obligation is also suspended on the condition of termination and since this termination condition is valid, it seems to have come into being because it is false and has never been realized. What follows from this statement is that an obligation suspended on the condition of termination is impossible or contrary to public order or good morals; completely and unconditionally created: Sometimes the condition of termination contrary to public order or good morals is the cause and motive for the payment of the obligation; for example, when a person promises to pay for a woman during her lifetime, provided that the woman has an illicit relationship with him and if the woman refuses to fulfill that condition, her obligation will be terminated, Here, the condition of termination is invalid and ineffective due to opposition to good morals, and according to the general rule required by Article 266 of the Egypt Civil law, the main obligation must remain in place after the condition has been revoked; However, since this condition (illegitimate relationship) in the mentioned case causes the payment of expenses by the obligor, the fall and invalidity of the condition also destroys the obligation with it. As the point; Second, Article 266 of the Egypt Civil law requires this. So both the condition of illegitimate stewardship and the obligation to pay both fall apart (Al-Sunuri, 2009, vol. 3: 32-31).

As mentioned, the condition for termination is the compromise that the two parties make regarding the possible termination of the contract in the future and thus limit the obligations arising from the contract to a certain time or the absence of special conditions; therefore, the termination condition should not be confused with the condition of the condition. Authority is the condition that either the seller or the customer, or both, stipulate that the termination authority is for them or a third party, the duration of which must be fixed.

In Article 399 of the Civil law, the authority of the condition is accepted and stipulated: In a contract of sale, it may be stipulated that the seller or the customer, or both, or a foreigner, has the right to terminate the transaction within a certain period of time.

Suspension of dissolution and option condition, both cause the contract to be dissolved and the obligation to fall. The power of bet gives one of the parties or both or a third party the right to terminate the contract within a certain period if they wish, while the result of the termination condition is the forced and spontaneous dissolution of the contract and no need to make another decision; That is, in the suspension of dissolution, with the realization of the suspension against, the contract is automatically terminated and there is no need for the will of either party to write. The difference between the termination condition and other suspension conditions is that in the termination condition, the contract occurs explicitly and the obligations arising from it arise and the fulfillment of the condition disturbs this situation and returns commitments. But in the condition of suspension, the effect of the contract is subject to the realization of an external accident; an event that, if it does not happen, will not lead to commitments (Al-Sunuri, 2009, vol. 3: 43-41).

The explanation of this matter is cleared by giving an example: For example, if the buyer says during the transaction that if the Iran Olympic convoy succeeds, I will buy this house, that is, the purchase of a house is conditional on success, this is a condition of suspension, but whenever he buys a house and at the same time it is stipulated that if the Iran convoy does not succeed in the Olympics, the sale will be canceled, this condition is terminated. Because of this difference, there is also a difference; in the first case, the house is transferred to the buyer after success, and in the second case, the transfer of ownership of the house occurs from the time of the sale (Katozian, 2008, J 5: 344).

Sometimes the creation of the right of discretion is suspended by something in which in these cases there is no right of discretion at all before the realization of the suspension against. In these cases, the emergence of the right of termination depends on the realization of something in the future .Sheikh Ansari, in his first possibility, had accepted the suspended right of termination and considered the rejection of the price suspended against the authority. It is obvious that the rejection of the price is not characteristic as suspended and any event can be considered suspended, of course, not only must the suspended person have a certain period of time, but also the time of discretion; For example, if a person sells his house to another, suspended if the seller's 
child marries within one year (one year for the suspension to take place), the seller has the right to terminate the contract for a period of two days (two days to exercise authority), this condition is the "suspended right to terminate". Article $458 \mathrm{BC}$ the "conditional sale" states:

In a contract of sale, intermediaries can stipulate that if the seller rejects all the same price to the customer within a certain period, has the right to terminate the transaction with respect to all buyers and they can also bet that whenever he rejects some like the price, has the power to terminate the transaction in respect of all or some of the seller. In any case, the right of discretion will be subject to the contract of the interlocutors, and if all or part of the price is not restricted to the price, the discretion will not be fixed, unless the full price is rejected.

In this case, if Article $458 \mathrm{BC}$. With this justification, that is, the first possibility of interpreting Sheikh Ansari, the difference between the sale of a condition (Article 458) and the option of a condition (Article 399) is that in the possession of a condition, the right to cancel is reserved, while in the sale of a condition, the creation of the right of cancellation is suspended.

It is noteworthy that assuming the acceptance of the first interpretation of Sheikh Ansari, i.e. the suspended right of termination, analytically, the difference between the suspended right of termination and the suspension of the dissolution of the contract, it should be said that in the suspension of dissolution, after the fulfillment of the suspended against, the contract is terminated automatically and without the need for a contract.

But in the case of suspended right of termination, only the right of termination is created after the realization of the suspended against, but there is no annulment, unless the beneficiary exercises his choice, which is termination, not annulment. For this reason, in Article $458 \mathrm{BC}$. Rejection of the price, if it is not the current termination, is only a suspended fulfillment to create the option of termination, and the termination needs to be written; Unless it is said that the rejection of the price is traditionally the current termination, which according to the appearance of Article 458 BC. Both inferences are correct.

In the case of termination, from the point of view of Egypt jurists, we said that an obligation that is suspended on the condition of termination, In fact, the obligation of deterioration and its disappearance is suspended on the condition of the knower; because the condition in all cases is the condition of the knower (suspended) that the existence of the obligation or the deterioration of the obligation ceases to be called in the first case, the condition of the knower and in the second case, the condition of termination.

In some cases, the identification of the termination condition is accurate from the deductible condition. For example, a person intends to sell a good and at the same time stipulates that he will sell the good with the consent of a third party. The question here is whether the condition contained in the contract is the condition of the knower that the contract of sale will take effect only with the consent of the person concerned or the termination condition is that the sale be concluded in a concise and effective manner and in case of disagreement of a third party, the sale is terminated.

Thus, it is very important to distinguish the termination condition from the suspension condition and sometimes when both parties do not express their intentions clearly, the judge gets into trouble; for example, if there is a contract that must be signed by the chairman of the company or the highest administrative official of a government agency, it is not clear whether the effect of the contract is subject to the signature of that official or whether his refusal to sign the contract will dissolve it?

In other words, what should be done if there is any doubt that the condition is suspended or corrupt?

In such an assumption, no rule can be presented. It seems that considering the relationship between the contract and the condition and the inside of the individuals, the judge should determine the nature of the condition based on the common intention of the two parties and in this search can be for all reasons in particular, ask for help from the situation and preliminary discussions and the articles of association of legal entities and the provisions of the law.

Another tool that the obligee can use to force the obligee to fulfill the obligation is the right of termination; that is, the obligor can use this legal authority to prevent the abuse of the obligor and, because of this right, to dissuade him from violating the obligation (Katozian, 2012, vol. 1). 
In Iran law, in order for the obligor to be able to use the guarantee of non-performance of the contractual obligation, and since Articles 226, $380 \mathrm{BC}$ and $532 \mathrm{BC}$ contain special rules, it seems difficult to accept the termination of the contract by the obligee as a general rule in Iran law; (Mubaraki, 2013) and the buyer, while terminating the contract, can also claim the contractual damages within the limits of the legal provisions (Article 386 BC) and the performance of the right of termination can be combined with the right to claim contractual damages.

\section{Discussion and Conclusion}

All jurists, both early and late, consider sale to be a kind of trade, and it has the same meaning in Iranian civil law. Examining the conditions of execution of sentences in the legal system of Egypt and Iran, it can be said that although there are differences regarding some conditions of execution between these two legal systems. But these differences are more than substantive due to differences in the scope of some concepts such as public order and the scope of its sub-topics, the remarkable thing about both legal systems is that the rules of both are very old and in some cases incompatible with the requirements of international private relations today, the existence of certain criteria, such as the condition of reciprocal behavior, is an important obstacle in the development of international private relations, to avoid these problems, countries consider foreign rulings to be compliant and enforceable in accordance with the rules and conditions, in Iranian law, the conditions for the execution of foreign judgments are set out in Article 169 of the Civil Judgments Enforcement Law of 1977, the Egyptian legislature, in Articles 296 and 298 of the 1968 Code of Civil Procedure, also stipulates conditions for the enforcement of foreign judgments.

The results of the article showed that there are many similarities in the law of Iran and Egypt regarding the obligations of the buyer and the seller. Payment of the price by the buyer and delivery of the goods by the seller are the most important obligations of the parties in the rights of both countries. In terms of guaranteeing the fulfillment of the obligations of the buyer and the seller, but there are differences. In civil law, one of the most important cases is the termination of the contract, according to Article 219 of the Civil law, which is binding on both parties, it may be terminated for various reasons, and the terminated contract creates new rights and obligations for the parties to the contract, including that upon termination of the contractual relationship, the parties to the contract are required to return the exchange and benefits, and in some cases it is possible to claim damages, in Iran law, the legislature has not assigned specific materials to the effects of termination, in general, in the various materials that deal with the termination of the contract, the effects of termination, dissolution of the contract and return of the exchange can be considered. The difference between Iran law and Egypt law is that in Iran law, unlike the mentioned systems, the effects of termination appear from the time of termination, not from the time of the contract, therefore, it leaves all its effects until the day the contract is terminated, therefore, the return of benefits is from the day of termination and another major difference is that in Iran law, deficiencies or the transfer of goods do not preclude termination, except in the case of a defect.

Well-known jurists and lawyers of Iran and Egypt believe in its permissibility and influence in the field of termination condition, and others, on the other hand, believe that the termination clause has no effect or validity. Egypt civil law states two important and basic conditions in both the condition of the knower condition and the termination condition. It is inferred from the text of Article 226 that when the condition of termination is impossible or contrary to public order or good morals, it is void.

\section{References}

Abu Al-Saud, Muhammad Ramadan. (2010). Explanation of the rules of civil law, contracts of the month, sale, rent, security, Beirut, legal publications, first edition.

Ali Ahmadi, Dr. Hossein. (1996). Execution of Contractual Obligations, Brahmand Publications, Winter. 
Al-Naraqiyyah, Al-Mawli Ahmad. (1987). Ayaf Al-Ayamfi, stating the rules of the rules and the importance of the issues of the righteous and the forbidden, the publications of the Insight School, Qom, Al-Qadir Press, Qom.

Al-Sharqawi, Jamil. (1975). Explanation of Civil Contracts, Sale and Controversy, Cairo.

Ameli, Sheikh Shams al-Din Muhammad ibn Maki ibn Ahmad. (1993). Lessons in the Science of Principles, Vol. 1, Printing House, Qom Islamic Publishing Institute.

Ameli, Sheikh Shams-ud-Din Mohammad bin Maki bin Ahmad. (2003). Sharh Lameh, vol.

Ansari, Sheikh Morteza. (1990). Makaseb, Volume 2, Second Edition, Qom, Ismailian Publications.

Darabpour, Mehrab. (2000). Comparative Evaluation of Commitment, Tehran Journal of Legal Research, Office of International Legal Services, No. 29, Spring and Summer.

Darabpour, Mehrab. (2012). A Commentary on International Sale Law, Volume 3, Tehran, Second Edition, Ganj-e-Danesh Publishing.

Emami, Seyed Hassan. (1994). Civil Law, Volume One, Tehran, Islamic Bookstore Publications.

Hosseini Al-Ameli, Seyyed Mohammad Javad. (1997). Muftah Al-Karama, Volumes 2 and 1, Dar Al-Tarath, Lebanon, Beirut.

Katozian, Nasser. (1989). General Rules of Contracts, Volume 2-3-3, First Edition, Behnshar Publications, December.

Katozian, Nasser. (1998). Ataya Civil Law, Volume 3, Tehran, Ganj-e-Danesh, Third Edition.

Katozian, Nasser. (2008). General Rules of Contracts, Volume 3, Fifth Edition, Tehran, Anteshar Co. Publications.

Katozian, Nasser. (2012). Civil Law, Certain Contracts, Volume One, Eleventh Edition, Tehran, Anteshar Publishing Company.

Khidmatgazar, Mohsen. (2008). Comparative study of the right of termination as one of the legal remedies for violating contractual obligations, Legal Research No. 47.

Khoei, Seyyed Abolghasem Al-Musawi. (1987). Mesbah al-Fiqha, Volume 7, Hajiani Publications, Najaf, Winter.

Lib Shnab, Mohammad; Majdi Sobhi, Khalil. (1975). Explanation of the rules of the sale contract. Dar Al-Nahda Al-Arabiya.

Mubaraki Hoshyar, Idris. (2013). A comparative study of the seller's commitment to surrender the seller of goods, No. 54.

Qasemzadeh, Seyed Morteza. (2009). Principles of Contracts and Obligations, Dadgostar Publishing, First Edition, Summer.

Qasim, Mohammad Hassan. (2008). Civil Law, Contracts of the Name of Sale-Security (Guarantee) -Ajjar-Comparative Studies, Legal Aleppo Publications, Beirut-Lebanon.

Rajeh, Mustafa Al-Jamal. (2000). Al-Sa'i Al-Al-Ta'qada, Demonstrations and Legal Works, AlDar Al-Jameieh, Beirut.

Sadeghi Neshat, Amir. (2009). The Right to Terminate a Contract Despite the Possibility of Obligation to Execute in Iran Law, Law Quarterly, Volume 39, Number 14, Winter.

Safaei et al., Seyed Hossein. (2011). International Sale Law, Third Edition, Tehran, Tehran University Press.

Sanhori, Abdul Razzaq. (2009). Al-Wasit Fi Sharh Al-Qanun Al-Madani, Volumes I and IV, Beirut, Dar Al-Ahya Al-Tarath Al-Arabi.

Shahidi, Mehdi. (2013). Falling of Obligations, Volume 5, Tehran, Majd Publications.

Sultan, Anwar. (1983). Al-Aqoud Al-Masma '(Explanation of the contract of sale and disputes), Beirut, Dar Al-Nahda Al-Arabiya. 